\title{
School Physical Environment and Student Academic Performance
}

\author{
Richard Kwabena Akrofi Baafi \\ Institute of Research on Adult Education and Knowledge Management, Eötvös Loránd University, Budapest, Hungary \\ Email: richbaafius@gmail.com
}

How to cite this paper: Baafi, R. K. A. (2020). School Physical Environment and Student Academic Performance. Advances in Physical Education, 10, 121-137. https://doi.org/10.4236/ape.2020.102012

Received: February 29, 2020

Accepted: May 11, 2020

Published: May 14, 2020

Copyright ( 2020 by author(s) and Scientific Research Publishing Inc. This work is licensed under the Creative Commons Attribution International License (CC BY 4.0).

http://creativecommons.org/licenses/by/4.0/

\section{(c) (i) Open Access}

\begin{abstract}
The study examined and compared the effect of the school physical environment on academic achievement of senior high school students in Ghana. The study sought to investigate the contribution of a number of school physical environment on the performance of students in schools. Participant for the study was selected using the multi-stage sampling technique using simple random sampling. A regression model was used to determine the relationship between the dependent and independent variables. The findings of the study confirmed that the students in senior high schools with a pleasant physical environment perform better than those where the learning environment is not conducive. The researchers, on the basis of the empirical evidence, established that adequate school facilities provide a positive educational climate suitable for student learning.
\end{abstract}

\section{Keywords}

Academic Performance, Physical Education, Learning, Education

\section{Introduction}

Education for years has been considered as playing functional roles in preparing individual learners to be socially useful and contribute meaningfully to national development. The process of learning is an active agent of change such that students are empowered to generate knowledge, form attitudes and develop requisite skills for life (Bada, 2015). The right to education to every Ghanaian child of school-going age is enshrined in the 1992 Constitution of the Republic of Ghana. The state is mandated to make the necessary resources and facilities available at all levels of the educational system so that the teaching and learning process can take place efficiently and effectively.

With Ghana's tenacity to empower national development through education, 
Ghana joined the United Nations cohort to observe the Sustainable Development Goals (SDGs) in 2015 which seeks with 17 goals to address global issues such as poverty eradication, protection of the earth, sustainable peace and prosperity. Among these goals, Goal 4 provides the education framework that leads to achieving equity and inclusiveness in the delivery of quality education and facilitates lifelong learning avenues to all persons (United Nations Development Programme, 2017). Ghana is making efforts to ensure that the SDGs' objectives are attained at various levels. The Ministry of Education (MOE) offers backing to the sector through the implementation of policies and programs to enhance the quality of education which is not restricted to the privileged in the society only but accessible to every citizen regardless of social status, gender and abilities.

All Ghanaian children who have attained school-going age are expected to acquire primary and secondary education freely and access quality and affordable tertiary education which includes technical and vocational training by the year 2030 for sustainable livelihood and acquisition of literacy and numeracy competencies (MOE, 2017). Unfortunately, there are concerns about the falling standards of the Ghanaian education system which could jeopardise the SDGs goals which is because statistics from the West African Secondary School Certificate Examinations (WASSCE) indicating that the percentage of high school graduates who failed their examinations ranged between $50 \%-70 \%$ in the last five years (Chowa, Masa, \& Tucker, 2013).

According to the West African Examination Council, 2012, the academic performance of JHS students in Ghana has been on the decline since 2009. General performance after BECE declined from in 2009 from $62.16 \%$ to $50.21 \%$ in 2008 , in 2010 , from $49.12 \%$ to $46.93 \%$ in 2011 . Ghana Education Service (2014), reported that out of the 51 candidates for 2010 BECE, none achieved a required grade of 6 - 10; only 9 had aggregate 11 - 30 while in 2011, out of the 34 candidates presented for the BECE, none achieved aggregate 6 - 10. 10 obtained aggregate $11-20$ and the other had 21 and above. The problem is not only in Ghana alone but also in other West African countries who also take part in the WASSCE report, reported similarly high rates of failures (Onweh \& Akpan, 2014).

The falling standards of academic performance of SHS students in Ghana constitute not just an educational challenge but also a developmental challenge in a country that seeks to use education as a vehicle for achieving development. Despite the tremendous progress in academic access for all Ghanaians, several problems are affecting thousands of school-going children from learning in schools. Most school environments in Ghana are not conducive to learning; students are overcrowded in classes; there are inadequate water and sanitation facilities. Most of all, the facilities do not favour the girl child in terms of menstrual hygiene management (MHM). The poor quality of education depicts the students' performance which is traceable to the school learning environment.

If the trend is left unchecked, high numbers of high school graduates will be 
released into the system with little human resource value. The urgent need for addressing the low academic performance at the SHS level in Ghana requires in-depth empirical research to understand the dynamics and the complexities of factors that shape academic achievement among students in SHS.

Despite having several empirical studies that have examined academic performance in different levels of education in Ghana and other African countries, there are still critical gaps in the current literature that requires further empirical evidence, for instance, the majority of the studies that examined academic performance-focused primarily or on either parents or student characteristics (Amponsah, Milledzi, Ampofo, \& Gyambrah, 2018), or teacher characteristics and teacher motivation (Costa \& Costa, 2016) or curriculum characteristics (Hervie \& Winful, 2018). These studies have examined these factors in isolation. While these factors studied could be said to influence students' academic performance, focusing on the elements in isolation may necessarily not provide insight into how these factors interact in complex ways to affect academic performance. Again, most studies available have become overly focused on tangible factors (i.e., teacher remuneration, educational facilities, curriculum development) that influence academic performance. There are equally important and more intangible factors like school environments that affect academic performance but may have escaped researchers at the global level and particularly in low and middle-income countries. These gaps have led to a limited understanding of what can predict students' academic performance in low and middle-income countries such as Ghana. Addressing these gaps provides in-depth knowledge of how different domains enhance the school learning environment in ways that impact students' academic performance differently.

The following research objectives, therefore, guided this study; to assess the effect of the school physical learning environment on students' academic performance in senior high schools in Ghana and to investigate the influence that students' characteristics have on academic performance in the context of the school physical learning environment.

\section{Literature Review}

\subsection{Theoretical Orientation}

The following theory and a model guided the study; School climate theory and the Integrated Conceptual Model of Student Success.

\subsubsection{School Climate Theory}

The school climate theory was developed by Gregory, Cornell and Fan (2011) to explain the various elements of how students experience their school environment.

The theory assumes that the interaction of varied factors creates a school learning environment in a school including the academic activities, safety, community and institutional environment that impact on the cognitive, behavioural and psychological development of students. Thus, school climate, how- 
ever it is formed, has both direct and indirect effect on students' outcomes in the school, including their academic performance (Gregory, Cornell, \& Fan, 2011).

In building the theory further, later researchers theorised elements of school climate that promote positive student development. For instance, Wang and Degol (2015), borrowing from research on parenting styles and child development argued that authoritative school climate promotes positive student development. They defined a positive school climate as one that offers a democratic atmosphere for students to express themselves. They used two leading indicators for authoritative school climate, which are democratic disciplinary structures and warmth student support (Wang \& Degol, 2015). In applying this theory to the current study, the school climate is used interchangeably with a school learning environment to signify various elements of the school environment that affect student learning in both direct and indirect ways. Thus, when the student learning environment is conducive, it will improve the academic performance of the students and vice versa.

\subsubsection{Integrated Conceptual Model of Student Success}

The integrated conceptual model of student success was developed by Perna and Thomas (2008) to explain the various factors that influence the success of students in school. The model argues that student success in school is influenced by multi-level factors both in school and at home. The factors they identified within the school context include facilities, rules and regulations and other factors that facilitate quality teaching and learning. The elements in the home context they identified are the extent to which families contribute to their children's education. In applying the model to the current study, the academic performance of students in secondary schools is presumed to be influenced by multi-level factors in both school and home context. In the case of the school context, the factors constitute a school learning environment, and in the case of the home context, parental school involvement is chosen. These factors form critical elements of the school climate or learning environment, which is hypothesised to impact academic performance directly.

\subsection{Empirical Orientation of Literature}

\subsubsection{The Physical Learning Environment}

The physical environment of a school includes buildings, classroom furniture, equipment, instructional materials, laboratories, libraries, playgrounds (Ene-Obong et al., 2012). The physical environment also is made up of machinery, decorative objects, swimming pools, audio-visual equipment and playfields (McKay, 1964). The physical environment implies the physical location, buildings, furniture, infrastructural facilities, space and equipment for effective teaching and learning.

The physical learning environment in the classroom includes the spatial arrangement of furniture, walls, ceiling, chalkboard, lighting, fittings, decorative and all the physical enablers of teaching and learning in the classroom. The conducive physical environment is an agent of intellectual stimulation and an 
essential factor in strengthening the child's educational development. The factors that determine the success of the educational process include the nature of the school, teacher's attitude and pupils' characteristics (Ukeje, Akabogu, \& Ndu, 1992). The classroom context, school and surrounding also influence students' achievement. The nature of the classroom environment has a powerful influence on how well students achieve a wide range of educational outcomes. Classroom environment such as physical, emotional and aesthetic characteristics of the classroom tend to enhance students' attitude towards learning (Goodlard, 1984).

According to Asiyai (2011), an appropriate learning environment is essential to safety and active learning and development. She maintained that such a situation is supportive and productive for functional training of head, heart and hand. All students and youth deserve a safe, respectful, caring and positive learning environment. The learning environment should foster a sense of belonging, enhance the joy of learning, honour, diversity and promote respectful, responsible and caring relationships. Nworgu (2006) contends that good healthful living calls for the provision of good lighting and ventilation, particularly in overcrowded classrooms, sewage and proper disposal of refuse. A review by Edmonds (1979) argued that one of the school factors that have contributed to creating effective instructional schools is an orderly but not oppressive school climate and a classroom surrounding conducive to the instructional process. Besides, Mgbodile (1997) contend that the school environment must be such that allows each student to increase his/her feelings of satisfaction, sense of belonging, identification and achievement in present and future situations, hi the light of the above, Davis-Langston (2012) noted that the environment of a school has the greatest of all influence that affects learning and academic performance of students.

\subsubsection{The Architecture of the Classroom and How They Influence Academic Performance}

In the school environment, factors such as acoustics, light, colour, temperature, and seat arrangement may improve or hinder students' academic performance in classrooms (Apter, 2014). The most significant factors affecting the learning process are noise, temperature and seat arrangement. Besides, there is no current agreement on how some particular physical characteristics of classrooms affect learning outcomes. Moreover, research would be needed to draw more reliable conclusions (Lewinski, 2015).

\subsubsection{Acoustics in the Classroom as Part of the School Learning Environment}

Noise, in general, is well known to have an impact on human performance. Chiang \& Lai (2008) investigated and identified adverse effects of working in a noisy room among young children.

They guarantee that noise impacts learning results, but also the health of the occupants. On account of little youngsters, they have not yet grown enough ex- 
ecutive skills in exercises including correspondence channels, similar to discourse appreciation, utilisation of language, and composed and oral aptitudes (Mills, 1975). Subsequently, obstruction significantly interferes with the way toward obtaining those fundamental limits in kids, and clamour is a long way from the main conceivable sort of mediation. Clamour under-mines perusing, composing and cognisance aptitudes, just as generally speaking scholastic execution, as sound makes it difficult to concentrate on the assignment or tasks given (Di Sarno et al., 2002).

Chiang \& Lai (2008) reviewed previous findings on noise's harmful effect on mental and physical wellbeing as part of their study. From a plethora of demonstrable impacts, the following adverse outcomes were reported in the context of a noisy room: getting tired quickly, leading to lower efficiency; increased heart rate; dyspepsia; poor appetite; insomnia; headache; tinnitus; and facial pallor. In a study by Zannin \& Zwirtes (2009), the researcher compared the different recommended structures of schools erected amid 1977-2005. Their findings were in tandem with early researches which established that classrooms were not comfortable places to acquire knowledge or to be mentally focused at all time, due to noise interference.

Zannin \& Zwirtes (2009), in his research, said that even if a standard and best design is selected, the results may be optimal for a pleasant learning environment. The study highlighted that the relative position of schoolyards and recreation spaces is often ill-conceived concerning the rest of the school. Besides, the architectural design and material choices allow for voice and noise to be carried between two adjoined classrooms and hallways.

Noise level is another critical issue when looking at how acoustics affects academic performance. No internationally recognised norms on maximum noise levels for classrooms exist, but, for example, Brazil's regulatory body has mandated a maximum of $40 \mathrm{~dB}(\mathrm{~A})$ (Zannin \& Marcon, 2007). Conversely, one well-controlled study of classroom noise levels revealed values over $40 \mathrm{~dB}(\mathrm{~A})$ for each of five tested classrooms with open and closed windows.

Teachers and students in the same study further pointed out that noise in the classroom was a significant reason for classroom distraction on students. The study interviewed 62 teachers and 462 students with specific questions on various acoustic aspects of classes. These interviews indicated that disturbing noise came mostly from other courses, especially during the adjournment of types. Both students and teachers speak loudly.

\subsubsection{Light in the Classroom as a Component of the School Learning Environment}

The quantity and quality of light (illumination) undoubtedly influences the perception of comfort in a particular space. Lighting has reliable and well-documented effects, but less evident in the case of the quality of light. In a study to evaluate how different types of lighting affect learning, Boray et al. (1989) evaluated warm white, cold white, and full-spectrum fluorescent and how they affect cog- 
nitive performance, room attractiveness, judged room size, and pleasure of room. The findings from the study established that there were no significant differences among all dependent variables concerning lighting types used. The management was found to prefer warm white or cool white to full-spectrum light because of the cost attached to the two which is relatively cheaper to buy and maintain. It is assumed that more light always creates a better, more favourable impression in the classroom. Nonetheless, one study noticeably shows an upper limit to classroom lighting, above which the illumination has adverse effects. Kruger \& Zannin (2004) surveyed in Brazil comparing luminance in classrooms throughout several days in August year 2000. One room was equipped with light shelves while the other one was not.

Classes were on a similar side of the structure, and every single other variable was held constant. Curiously, these investigations demonstrated that rooms with light retire and without light retires condition had focal points and hindrances. During the late afternoon, windows with light shelves produced light below prescribed luminance, whereas windows without light shelves created high luminance values throughout the day, which can lead to gradual furniture and fixture damage and distract students and teachers as well as increase thermal discomfort. This examination shows that even such element like light shelves may have some downsides.

\subsubsection{Color in the Classroom as an Aspect of School Learning Environment}

Effects of exposing people to particular colours have always intrigued scientists. Colour most certainly affects our worldly experience. Seemingly, an ongoing debate concerns the peculiarly named colour "baker-miller pink", which is purported to lower stress and anxiety levels, as well as affecting physiological functions, for example, reducing blood pressure and pulse rate (Schauss, 1985; Profusek \& Rainey, 1987; Bennett et al., 1991).

Going back to a study conducted by Gilliam and Unruh as far back as 1988 noted that the results of studies on baker-miller pink were incongruent with each other. Consequently, Gilliam and Unruh (1988) investigated the topic themselves, finding no significant differences between peoples' experience of and reactions to ordinary white walls and the more unusual baker-miller pink walls.

A study by Elliot et al. (2007) exposed participants to the colour red, green, or black before giving them a test; they found that exposure to red, even if participants were not consciously aware of the disclosure, impaired their academic performance. The effect was observed even when a number was written in red ink at the top of a sheet of paper. Greater right frontal hemisphere EEG activation was observed when students were exposed to red, which is consistent with similar findings of greater activation in right frontal relative to the left frontal cortex following exposure to the colour red. Another argument for the adverse effects of the colour red pertains to findings by Gimbel (1997) and Pile (1997), which are summarised in a table as part of their research paper (Gimbel, 1997; 
Pile, 1997). Notably, these authors suggest that the colour green is best for schoolrooms. Gimbel (1997) and Pile (1997) in their study table, also suggest the colours that might be responsible for specific student behaviours, e.g., red-alert, increased pulse, activity; green-balance, judgment, arrested movement, stasis. However, in his book on environmental psychology, Gifford (2007) argues that performance on math and reading tests did not vary among students who performed in classrooms with different coloured walls.

In a short review of how to design productive study environments, Stone (2001) highlights the lack of a clear relationship between colour and mood (working from the assumption that feeling is unswervingly associated to performance). Grounded on a review of dozens of studies, Stone observes that if any relationship does exist, the most likely associations are red and yellow colours with stimulation and blue and green colours with calming effects. Stone also found out that colour did have an impact on qualitatively different tasks (math task versus reading assignment). The intensity of the surrounding environment affected performance on more difficult tasks, i.e., the reading task. A further finding was that the lowest return on cognitively demanding tasks was in classrooms with red walls.

\subsubsection{Classroom Temperature and How It Affects the School Learning Environment}

We dispute that temperature plays a vital role in how comfortable we are likely to feel when executing a task. Perhaps the supreme temperature is one that is hardly noticeable - neither too cold nor too hot. Unsurprisingly, the temperature of classrooms is another crucial influence that contributes to students' academic achievement. In a literature review of thermal quality and students' learning, Earthman (2002) highlighted the existence of prime temperature ranges for optimal learning outcomes. Generally, research shows that temperatures between 68 and $74^{\circ} \mathrm{F}-20$ and $24^{\circ} \mathrm{C}$-are most conducive to comfort and, by extension, learning. Besides, $50 \%$ of relative humidity was found to be an acceptable value for classrooms (Earthman, 2002). There is an association between classroom temperature and acoustics. Classroom air conditioning systems may produce considerably uncomfortable noise.

\subsubsection{Seating Arrangement in the Classroom and How They Affect the School Learning Environment}

We contend that the seat arrangement is a potent means to efficiently manipulate the physical characteristics of the school to ensure high performance of both students and teachers. Douglas \& Gifford's (2001) research incorporated a lens model approach - a probabilistic representation of the way perceivers use environmental cues to draw inferences about the environment-, which was initially advanced by Brunswik (1956). Students and professors, who assess classroom physical characteristics, might not at first glance be related to issues of academic performance. However, Douglas \& Gifford's (2001), at the beginning of their study, the researchers modified a lens model to twinset their desires. Professors 
and Students the study judged how friendly the classroom was and how much they preferred it. Douglas \& Gifford (2001) explained how friendliness and overall preference, as described in the questionnaire. Kindness was defined as "how warm, comfortable, etc., the room makes you feel in your own opinion". Overall preference was described as "a global rating of all factors that you consider important to the classroom environment". Every member was shown two photos of 35 various classrooms, and she evaluated them on the scale just described. Surprisingly, only three characteristics of the school explained between $40 \%$ and $57 \%$ of the variance in the evaluation of friendliness and overall preference by both students and professors. Some people preferred societal arrangements of seats. The sociopetal agreement is defined as the placement of chairs and tables in a way that it allows for more significant social dealing midst students and university professors. Two additional notable properties were of a view of the outdoors and comfortable seats. Not surprisingly, the quality of seating was more significant for students, as teachers tend to have comfortable seats owing to their higher status. Douglas \& Gifford (2001) pointed out that users of classrooms did not rate highly such classroom properties as brightness, room size and aesthetic complexity.

The investigation of Douglas \& Gifford (2001) offers no insights regarding how these various classroom properties are related, nor if they individually or together relate to the learning process. On the other hand, we argue that it is sensible to assume that physical characteristics famous for eliciting positive feelings and making people relaxed in the learning environment must be strongly correlated with the performance of the students

Studying in an appealing classroom, therefore, is far preferable to being in a school without social seating arrangements, a view to the outdoors, and comfortable seats. This assertion remains to be tested, however. Rosenfield et al., (1985) examined how desk and chair arrangement affected students' behaviour. School going children in elementary classes were assessed according to their on-task expressions, such as hand-raising, discussion comment, questioning/ pupil request, listening, out-of-order comment, and speaking; and on their off-task behaviours, such as withdrawal, aggression and disruptive conduct. The dependent variables mentioned above were clearly defined and measured by trained evaluators. The possible desk arrangements were clusters, rows, and circles. Results showed that students seated in circles showed the most on-task behaviours. The second-best arrangement of desks and chairs was a cluster arrangement, and the least effective was desks arranged in rows. As expected, such variables as sex, age, and attitude toward studying affected students' scoring too.

\subsubsection{The Perception of Secondary School Students on the Physical Learning Environment}

The opinion of secondary school students on the condition of their classroom physical learning environment and its impact on their learning was investigated. Findings emerging from data analysis revealed that private school students dif- 
fered significantly in their perception of the condition of their classroom physical learning environment than public school students. There was no significant difference between the understanding of male and female students on the state of their classroom physical learning environment. A significant difference existed between the knowledge of urban and rural school students on the status of their classroom physical learning environment. The finding further revealed that the state of classroom physical learning environment had a significant impact on students' learning and motivation including the motivation to actively participate in academic activities; it can influence their behaviour and their school attendance.

\section{Data and Methods}

The study employed descriptive survey research. The study adopted a descriptive survey design to examine the hypotheses of the school physical learning environment. The survey method was employed because it was deemed more advantageous in capturing large sample to generalise the findings. Also, the survey was used since it provided self-reported data from the students based on how they experienced their school physical learning environment. The target population of study for this study was all students in senior high schools in the Greater Accra Region of Ghana. The senior high schools involved are government-assisted and public schools located in the Accra Metropolis. The selection of the region was based on some factors. According to some statistics of past WASSCE results, students in senior high schools of the Greater Accra Region performed relatively better than students in other regions (MOE, 2017; World Bank, 2018). Again, the region was considered appropriate for such a study because it is the region that houses the national capital as well as the political and economic administration of the country. The MoE and Ghana Education Service in their 2016 annual reports cited that the Greater Accra Region has the highest number of senior high schools in the country. Additionally, since the regional capital of the region, Accra happens to be the main economic nerve of Ghana, the region's senior high schools attract students from all over the country from different socio-economic backgrounds. All these indicators informed the researcher's choice of the region to be most suitable for this study because the findings may be representational of Ghana as a whole. The sample selection for the study was approached at two-level; at the schools' level and the students' level. At the schools' level, the selection process put all the senior high schools within the Accra metropolis into two strata based on their location in the city's local government administration namely municipal assembly and metropolitan assembly. Two senior high schools were selected in each stratum with one school being run as a day senior high school and the other a boarding senior high school. This was followed by the process of selecting students in the selected senior high schools participating in the study. The four senior high schools were purposefully selected for the study in line with the research's objectives. Descriptive and inferential statistics were 
used to present the research findings with the help of SPSS.

\section{Discussions and Findings}

This study evaluated the relationship between school physical learning environment and academic performance in the context of the demographic characteristics of the student's understudy. It sought to add to existing knowledge the influence that the characteristics of the students under study bring to bear on academic performance defined by the school physical learning environment.

The findings from Table 1 showed that the means of All the classrooms in my school had got furniture and In my school, students can get access to the school library at any time questions of the research were 3.75 and 3.63 with standard deviations of 1.261 and 1.407 respectively. This showed that the variations in responses from one respondent to another were minimal. Therefore the respondents felt that all their schools had furniture and accessing school library by ant student was very easy. In addition to that, the respondents agreed that their school had an entertainment hall. Lastly, the respondents agreed strongly on the following variables. That the security men are strict in their school, the school changes over to a generator plant always whenever the national electricity grid goes off, different kinds of food are sold in the school's canteen, their school has a sickbay and that the school needs more boarding facilities.

From Table 2, all the variables were included in the regression model. Nome was excluded or removed. The model was conducted with eight variables as independent variables.

Table 1. Measures of school physical environment.

\begin{tabular}{lcc}
\hline \multicolumn{1}{c}{ Variable } & Mean & Std. Deviation \\
\hline All the classrooms in my school have got furniture & 3.75 & 1.261 \\
$\begin{array}{l}\text { In my school the security men are strict } \\
\text { My school changes over to a generator plant always whenever }\end{array}$ & 4.19 & 1.052 \\
$\begin{array}{l}\text { the national electricity grid goes off } \\
\text { In my school, students can get access to the school library at any time }\end{array}$ & 3.11 & 1.168 \\
$\begin{array}{l}\text { Different kinds of food are sold in my school's canteen } \\
\text { My school has an entertainment hall }\end{array}$ & 4.16 & 1.407 \\
My school has a sickbay & 3.16 & 1.147 \\
My school needs more boarding facilities & 4.39 & .954 \\
\hline
\end{tabular}

Table 2. Regression analysis.

\begin{tabular}{|c|c|c|c|}
\hline \multicolumn{4}{|c|}{ Variables Entered/Removed ${ }^{\mathrm{a}}$} \\
\hline Model & Variables Entered & Variables Removed & Method \\
\hline 1 & $\begin{array}{l}\text { SPE30, SPE28, SPE23, SPE27, } \\
\text { SPE26, SPE24, SPE29, SPE25 }\end{array}$ & . & Enter \\
\hline
\end{tabular}

a Dependent Variable: MEANSCORE; b. Tolerance $=.000$ limit reached. 
From the model summary in Table $3,89.1 \%$ of the variables contribute to the regression model. $89.1 \%$ of the variance in the dependent variable is accounted for by the independent variables. This means that our regression model can be relied upon in making inferences with regard to the school physical environment and student performance. $\mathrm{R}$ square shows the level of correlation between the dependent and independent variable.

The findings from Table 4 show that the regression model predicts the dependent variable significantly well. This is based on the sig value of .000 , which indicates the statistical significance of the regression model above sig Value $<.002$, which is less than .05 . We, therefore, conclude that, overall, the regression model statistically significantly predicts the outcome variable meaning that it is a good fit for the data. The coefficients were as shown in Table 5.

The findings from the regression analysis in Table 5 showed that the following have positive relationships with student performance. All the classrooms in my school have got furniture, school changes over to a generator plant always

Table 3. Model summary.

\begin{tabular}{ccccc}
\hline Model & R & R Square & Adjusted R Square & Std. Error of the Estimate \\
\hline 1 & $.891^{\mathrm{a}}$ & .631 & .638 & .207
\end{tabular}

aPredictors: (Constant), SPE30, SPE28, SPE23, SPE27, SPE26, SPE24, SPE29, SPE25.

Table 4. ANOVA.

\begin{tabular}{ccccccc}
\hline & Model & Sum of Squares & df & Mean Square & F & Sig. \\
\hline \multirow{3}{*}{1} & Regression & 22.152 & 8 & 2.769 & 1.703 & $.002^{\mathrm{b}}$ \\
& Residual & 586.915 & 361 & 1.626 & & \\
& Total & 609.067 & 369 & & & \\
\hline
\end{tabular}

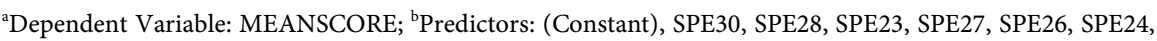
SPE29, SPE25.

Table 5. Coefficients.

\begin{tabular}{|c|c|c|c|c|c|c|c|c|}
\hline & \multirow[t]{2}{*}{ Model } & \multicolumn{2}{|c|}{$\begin{array}{l}\text { Unstandardized } \\
\text { Coefficients }\end{array}$} & \multirow{2}{*}{$\begin{array}{c}\begin{array}{c}\text { Standardised } \\
\text { Coefficients }\end{array} \\
\text { Beta }\end{array}$} & \multirow[t]{2}{*}{$t$} & \multirow{2}{*}{ Sig. } & \multicolumn{2}{|c|}{$\begin{array}{c}\text { Collinearity } \\
\text { Statistics }\end{array}$} \\
\hline & & B & Std. Error & & & & Tolerance & VIF \\
\hline \multirow{9}{*}{1} & (Constant) & 7.786 & .517 & & 15.063 & .000 & & \\
\hline & SPE23 & .027 & .055 & .027 & .501 & .616 & .931 & 1.075 \\
\hline & SPE24 & -.177 & .102 & -.145 & -1.734 & .014 & .383 & 2.609 \\
\hline & SPE25 & .179 & .084 & .163 & 2.131 & .024 & .456 & 2.192 \\
\hline & SPE26 & .032 & .050 & -.035 & -.645 & .009 & .905 & 1.105 \\
\hline & SPE27 & -.124 & .061 & -.110 & -2.015 & .045 & .890 & 1.124 \\
\hline & SPE28 & -.082 & .044 & -.099 & -1.880 & .061 & .954 & 1.049 \\
\hline & SPE29 & .087 & .098 & .065 & .889 & .375 & .501 & 1.995 \\
\hline & SPE30 & -.051 & .083 & -.033 & -.614 & .539 & .934 & 1.071 \\
\hline
\end{tabular}

${ }^{\mathrm{a} D e p e n d e n t ~ V a r i a b l e: ~ M E A N S C O R E . ~}$ 
whenever the national electricity grid goes off, In my school, students can get access to the school library at any time, and the school has a sickbay. All these have a positive influence on student academic performance. The other variables have an inverse relationship with academic performance based on the findings of the study. They include, in the school the security men are strict, Different kinds of food are sold in my school's canteen, the school has an entertainment hall, and the school needs more boarding facilities. There was a significant influence on the following variables on the student academic performance since the P-value was less than .00. in the school the security men are strict, the school changes over to a generator plant always whenever the national electricity grid goes off, in the school, students can get access to the school library at any time and availability of different kinds of food are sold in my school's canteen (Table 6 \& Table 7).

\section{Conclusion and Recommendation}

The study explicitly endorsed the importance of the school learning environment in determining student academic performance. The findings of the study confirmed that the students in senior high schools with a pleasant physical environment perform better than those where the learning environment is not conducive. The researchers, on the basis of the empirical evidence, adduced concluded that adequate school facilities provide a positive educational climate

Table 6. Excluded variables.

\begin{tabular}{|c|c|c|c|c|c|c|c|c|}
\hline & \multirow{2}{*}{ Model } & \multirow{2}{*}{ Beta In } & \multirow{2}{*}{$\mathrm{t}$} & \multirow{2}{*}{ Sig. } & \multirow{2}{*}{ Partial Correlation } & \multicolumn{3}{|c|}{ Collinearity Statistics } \\
\hline & & & & & & Tolerance & VIF & Minimum Tolerance \\
\hline 1 & MEANSPE &. $\mathrm{b}$ & . & . & . & .000 & . & .000 \\
\hline
\end{tabular}

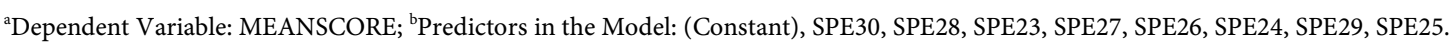

Table 7. Collinearity diagnostics.

\begin{tabular}{|c|c|c|c|c|c|c|c|c|c|c|c|c|}
\hline \multirow{2}{*}{ Model } & \multirow{2}{*}{ Dimension } & \multirow{2}{*}{ Eigenvalue } & \multirow{2}{*}{$\begin{array}{l}\text { Condition } \\
\text { Index }\end{array}$} & \multicolumn{9}{|c|}{ Variance Proportions } \\
\hline & & & & (Constant) & SPE23 & SPE24 & SPE25 & SPE26 & SPE27 & SPE28 & SPE29 & SPE30 \\
\hline \multirow{9}{*}{1} & 1 & 8.455 & 1.000 & .00 & .00 & .00 & .00 & .00 & .00 & .00 & .00 & .00 \\
\hline & 2 & .172 & 7.019 & .00 & .01 & .00 & .00 & .02 & .00 & .97 & .00 & .00 \\
\hline & 3 & .111 & 8.741 & .00 & .00 & .02 & .02 & .81 & .00 & .01 & .01 & .01 \\
\hline & 4 & .095 & 9.434 & .00 & .76 & .01 & .03 & .08 & .00 & .00 & .00 & .00 \\
\hline & 5 & .069 & 11.046 & .01 & .11 & .03 & .08 & .05 & .43 & .00 & .00 & .04 \\
\hline & 6 & .049 & 13.187 & .03 & .02 & .00 & .04 & .01 & .50 & .00 & .00 & .25 \\
\hline & 7 & .023 & 19.358 & .01 & .01 & .08 & .57 & .02 & .01 & .00 & .47 & .05 \\
\hline & 8 & .015 & 23.760 & .06 & .00 & .77 & .24 & .00 & .01 & .00 & .48 & .02 \\
\hline & 9 & .012 & 26.402 & .88 & .09 & .08 & .01 & .01 & .05 & .02 & .03 & .63 \\
\hline
\end{tabular}

${ }^{\mathrm{a} D e p e n d e n t ~ V a r i a b l e: ~ M E A N S C O R E . ~}$ 
suitable for student learning. The study, therefore, recommended that

1) In the Ministry of Education (MOE) in Ghana, policymakers need to insist on material standardization and availability of learning resources in schools. They also need to recommend a standard structure of the classroom and materials that are required in schools in order to promote active student learning in schools. There is a need to conduct a comparative study between public and private schools to ascertain if private schools have better physical environment than senior public schools.

2) The study recommends headteachers of schools should make efforts to ensure that the standard design of schools is adhered to and ensure that all the required resources are available in schools to promote excellent student performance in class.

3) The physical layout of classrooms should be well structured and the physical facilities provided to schools according to student needs.

4) There is a need to replace chalkboards with whiteboards to increase teaching effectiveness. Classrooms should have enough light to support learning. Schools install generators and other power backups so that education cannot be interrupted during electricity blackouts.

5) All the classrooms should be decorated with visual teaching aids like maps, charts, posters and murals to increase the interest, attentiveness and motivational level of the students.

6) Classroom walls should be well painted with learner support paints.

\section{Conflicts of Interest}

The author declares no conflicts of interest regarding the publication of this paper.

\section{References}

Amponsah, M. O., Milledzi, E. Y., Ampofo, E. T., \& Gyambrah, M. (2018). Relationship between Parental Involvement and Academic Performance of Senior High School Students: The Case of Ashanti Mampong Municipality of Ghana. American Journal of Educational Research, 6, 1-8.

Apter, M. J. (2014). Towards a Theory of Things: Reversal Theory and Design. Journal of Motivation, Emotion, and Personality, 2, 3-11. https://doi.org/10.12689/jmep.2014.302

Asiyai, R. (2011). Effective Classroom Management Techniques for Secondary Schools. African Research Review, 5, 282-291.

Bada, S. O. (2015). The Psychogenesis of Knowledge and Its Epistemological Significance. Language and Learning, 5, 23-34.

Bennett, C. P., Hague, A., \& Perkins, C. (1991). The Use of Baker-Miller Pink in Police Operational and University Experimental Situations in Britain. International Journal of Biological and Medical Research, 13, 118-127.

Boray, P. F., Gifford, R., \& Rosenblood, L. (1989). Effects of Warm White, Cool White and Full-Spectrum Fluorescent Lighting on Simple Cognitive Performance, Mood and Ratings of Others. Journal of Environmental Psychology, 9, 297-307. https://doi.org/10.1016/s0272-4944(89)80011-8 
Brunswik, E. (1956). Perception and the Representative Design of Psychological Experiments. Berkley and Los Angeles, CA: University of California Press.

Chiang, C., \& Lai, C. (2008). Acoustical Environment Evaluation of Joint Classrooms for Elementary Schools in Taiwan. Building and Environment, 43, 1619-1632. https://doi.org/10.1016/j.buildenv.2007.10.014

Chowa, G., Masa, R., \& Tucker, J. (2013). The Effects of Parental Involvement on Academic Performance of Ghanaian Youth: Testing Measurement and Relationship Using Structural Equation Modeling. Children and Youth Services Review, 35, 65-72. https://doi.org/10.1016/j.childyouth.2013.09.009

Costa, M., \& Costa, L. (2016). Science and Mathematics Instructional Strategies, Teaching Performance and Academic Achievement in Selected Secondary Schools in Upland. International Journal of Educational and Pedagogical Sciences, 3.

Davis-Langston, C. (2012). Exploring Relationships among Teaching Styles, Teachers' Perceptions of Their Self Efficacy and Students' Mathematics Achievement. Doctoral Dissertation, Retrieved from ProQuest Dissertations \& Theses Database (UMI No. 3495972).

Di Sarno, N. J., Schowalter, M., \& Grassa, P. (2002). Classroom Amplification to Enhance Student Performance. Teaching Exceptional Children, 34, 20-26.

https://doi.org/10.1177/004005990203400603

Douglas, D., \& Gifford, R. (2001). Evaluation of the Physical Classroom by Students and Professors: A Lens Model Approach. Educational Research, 43, 295-309. https://doi.org/10.1080/00131880110081053

Earthman, G. (2002). School Facility Conditions and Student Academic Achievement. Williams Watch Series: Investigating the Claims of Williams v. State of California, Los Angeles, CA: UCLA's Institute for Democracy, Education, and Access. http://www.escholarship.org/uc/item/5sw56439

Edmonds, R. (1979). Effective School for the Urban Poor. Educational Leadership, 37, 15-27.

Elliot, A. J., Maier, M. A., Moller, A. C., Friedman, R., \& Meinhardt, J. (2007). Color and Psychological Functioning: The Effect of Red on Performance Attainment. Journal of Experimental Psychology: General, 136, 154-168. https://doi.org/10.1037/0096-3445.136.1.154

Ene-Obong, H., Ibeanu, V., Onuoha, N., \& Ejekwu, A. (2012). Prevalence of Overweight, Obesity, and Thinness among Urban School-Aged Children and Adolescents in Southern Nigeria. Food and Nutrition Bulletin, 33, 242-250. https://doi.org/10.1177/156482651203300404

Gifford, R. (2007). Environmental Psychology. Colville, WA: Optimal Books.

Gilliam, J. E., \& Unruh, D. (1988). The Effects of Baker-Miller Pink on Biological, Physical and Cognitive Behaviors. Journal of Orthomolecular Medicine, 5, 202-206.

Gimbel, T. (1997). Healing with Colour. London: Gaia.

Goodlad, J. I. (1984). Introduction: The Uncommon Common School. Education and Urban Society, 16, 243-252. https://doi.org/10.1177/0013124584016003001

Gregory, A., Cornell, D., \& Fan, X. (2011). The Relationship of School Structure and Support to Suspension Rates for Black and White High School Students. American Educational Research Journal, 48, 904-934. https://doi.org/10.3102/0002831211398531

Hervie, D. M., \& Winful, E. C. (2018). Enhancing Teachers' Performance through Training and Development in Ghana Education Service (A Case Study of Ebenezer Senior High School). Journal of Human Resource Management, 6, 1-8. 
https://doi.org/10.11648/j.jhrm.20180601.11

Kruger, E. L., \& Zannin, P. H. T. (2004). Acoustic, Thermal and Luminous Comfort in Classrooms. Building and Environment, 39, 1055-1063. https://doi.org/10.1016/j.buildenv.2004.01.030

Lewinski, P. (2015). Effects of Classrooms' Architecture on Academic Performance in View of Telic versus Paratelic Motivation: A Review. Frontiers in Psychology, 6, 746. https://doi.org/10.3389/fpsyg.2015.00746

McKay, R. L. (1964). How to Keep School Noise at the Right Level. The Nation's Schools, 74, 64-67.

Mgbodile, T. (1997). The Nature and Scope of Educational Administration and Management. In A. Ndu, L. Ocho, \& B. Okeke (Eds.), Dynamics of Educational Administration and Management. The Nigerian Perspective. Awka: Meks Publisher Ltd.

Mills, J. H. (1975). Noise and Children: Are View of Literature. The Journal of the Acoustical Society of America, 58, 767-779. https://doi.org/10.1121/1.380748

Ministry of Education (MOE) (2017). Medium Term Expenditure Framework (MTEF) for 2017-2019. https://www.mofep.gov.gh/sites/default/files/pbb-estimates/2017/2017-PBB-MOE.pdf

Nworgu, B. G. (2006). Educational Research: Basic Issues and Methodology (Second and Enlarged Edition). Nsukka: University Trust Publishers.

Onweh, V. E., \& Akpan, U. T. (2014). Instructional Strategies and Students' Academic Performance in Electrical Installation in Technical Colleges in Akwa Ibom State: Instructional Skills for Structuring Appropriate Learning Experiences for Students. International Journal of Educational Administration and Policy Studies, 6, 80-86. https://doi.org/10.5897/IJEAPS2014.0347

Perna, L. W., \& Thomas, S. L. (2008). Theoretical Perspectives on Student Success: Understanding the Contributions of the Disciplines. ASHE Higher Education Report, 34, $1-87$.

Pile, J. (1997). Colour in Interior Design. New York: McGraw-Hill.

Profusek, P. J., \& Rainey, D. W. (1987). Effects of Baker-Miller Pink and Red on State Anxiety, Grip Strength, and Motor Precision. Perceptual and Motor Skills, 65, 941-942. https://doi.org/10.2466/pms.1987.65.3.941

Rosenfield, P., Lambert, N. M., \& Black, A. (1985). Desk Arrangement Effects on Pupil Classroom Behavior. Journal of Educational Psychology, 77, 101-108. https://doi.org/10.1037/0022-0663.77.1.101

Schauss, A. G. (1985). The Physiological Effect of Color on the Suppression of Human Aggression: Research on Baker-Miller Pink. International Journal of Biosocial Research, 2, 55-64.

Stone, N. (2001). Designing Effective Study Environments. Journal of Environmental Psychology, 21, 179-190. https://doi.org/10.1006/jevp.2000.0193

Ukeje, B. O., Akabogu, G. C., \& Ndu, A. (1992). Educational Administration. Enugu: Fourth Dimension.

Wang, M.-T., \& Degol, J. (2015). School Climate: A Review of the Construct, Measurement, and Impact on Student Outcomes. Educational Psychology Review, 28, 315-352. https://doi.org/10.1007/s10648-015-9319-1

World Bank (2018). Learning to Realize Education's Promise. Washington DC. https://doi.org/10.1596/978-1-4648-1096-1

Zannin, P. H. T., \& Marcon, C. R. (2007). Objective and Subjective Evaluation of the 
Acoustic Comfort in Classrooms. Applied Ergonomics, 38, 675-680. https://doi.org/10.1016/j.apergo.2006.10.001

Zannin, P. H. T., \& Zwirtes, D. P. Z. (2009). Evaluation of the Acoustic Performance of Classrooms in Public Schools. Applied Acoustics, 70, 625-635.

https://doi.org/10.1016/j.apacoust.2008.06.007 